\title{
ALIENADOS E DARANDINS: \\ FRONTEIRAS (DES)IDENTITÁRIAS NOS CONTOS \\ DE LOUCOS DE ROSA E MACHADO
}

\section{ALIENATED BEINGS AND DARANDINS: (DIS)IDENTITARY FRONTIERS IN TALES OF CRAZY FROM ROSA AND MACHADO}

Ravel Giordano Paz

RESUMO: O trabalho realiza um percurso comparativo por três contos que têm figuras de loucos em seu centro - "Darandina" e "Sorôco, sua mãe, sua filha", de Guimarães Rosa, e "O alienista", de Machado de Assis -, discutindo as formas que a loucura assume neles e suas relações com a idéia e as demandas de uma certa coletividade, sobretudo a dupla e instável necessidade de romper e manter os limites identitários da dita "normalidade".

PALAVRAS-CHAVE: loucura, literatura brasileira comparada, Guimarães Rosa, Machado de Assis.

ABSTRACT: The work performs a comparative journey for three short stories that have figures of crazies in its center - "Darandina" and "Sorôco, sua mãe, sua filha" by Guimarães Rosa, and "O alienista" by Machado de Assis -, discussing the meanings that madness assume in these short stories and its relations with the idea and the demands of a certain collectivity, in particular, the dual and unstable need of break and keep the identitary limits of the supposed "normality".

KEY WORDS: madness, Brazilian compared literature, Guimarães Rosa, Machado de Assis.

* Professor da Universidade Estadual de Goiás (UEG), campus de Quirinópolis. E-mail: ravelgp@yahoo.com.br. 



\section{ALIENADOS E DARANDINS: FRONTEIRAS (DES)IDENTITÁRIAS NOS CONTOS DE LOUCOS DE ROSA E MACHADO}

\section{Introduzindo}

Entre os muitos interesses comuns a Guimarães Rosa e Machado de Assis - aproximação que uma chamada para artigos sobre esses dois escritores torna uma tentação difícil de evitar -, um muito evidente é o tema da loucura. Mas falar sobre a loucura é uma operação paradoxal, ou, mais ainda, que nos defronta de forma incisiva com as aporias que rondam qualquer concepção dita racional da vida e do mundo; uma operação que coloca em xeque as condições de possibilidade do próprio discurso sobre o mundo - ou seja, do discurso sobre um outro -, na medida em que evidencia a precariedade de qualquer enunciação "compreensiva" em relação a um dado "fenômeno" ou "objeto", ao defrontá-la com singularidades radicalmente esquivas a ela. É com toda seriedade - "sério, creio que, pela primeira vez" - que um certo dr. Bilôlo enuncia essas palavras: "A vida é constante, progressivo desconhecimento..." ("Darandina”, in ROSA, 1964, p. 149). E se é verdade que um outro alienista, talvez o mais conhecido de nossa literatura, jamais chegou a essa constatação - pelo contrário, é um conhecimento positivo o que Simão Bacamarte acredita ter alcançado com sua "nova doutrina” -, também veremos que a diferença entre ela e a sua própria não deixa de ser extremamente sugestiva, além de bastante relativa. Assim, assumindo 
essa condição paradoxal que é discursar, ainda que indiretamente - ou seja, de forma mediada pelo texto literário -, sobre o louco, também convém dizer desde logo que é no movediço espaço entre essas duas conclusões que tentaremos enunciar as nossas próprias.

Mas para suportar minimamente essa situação paradoxal, é necessário que esses extremos constituam de fato de um espaço, e não uma dicotomia: um espaço habitado por outras vozes, de loucos e pretensos "normais", que é preciso seguir para, em alguma medida, falar junto com elas. Pois não é exatamente essa a possibilidade - ou, que seja, a ilusão - que a arte narrativa nos oferece? Não obstante, mesmo as polaridades (assim como os loucos, por sinal), têm as suas razões de ser; aliás, elas trazem consigo a força, quem de quantas, das múltiplas "razões" que informam os conceitos e experiências humana, cultural e/ou historicamente compartilhados. Pois o fato é que por mais que o louco - ou seja, um louco em particular -, escape à camisa de força dos esquemas e dualidades da razão (seja ela "humana", "ocidental" ou "moderna"), é no interior deles que sua "recepção" por nós está fadada a situá-lo, ainda que num primeiro momento. Por mais alheio que esse louco seja, por exemplo, a uma dialética (e um sentimento) de ser e não-ser, de presença e ausência, para nós - e o outro é sempre um para nós -, ele não pode deixar de se situar no interior dessas polaridades; por vezes, simplesmente, como o habitante do pólo contrário ao que, muito tranqüila e ingenuamente, reivindicamos para nós, mas por vezes como terreno de uma agonística desses pólos: a ameaça de um não-ser e/ou o excesso de um ser, este não raro se afigurando tão espantoso e ameaçador quanto aquela.

Seja como for, visto de perto o louco parece emanar não apenas a fraqueza de uma "falta" (a da "razão"), mas também uma outra força: a força de uma injunção enigmática. Esse enigmático assinala, para nós, um corte ou uma distância em relação ao outro, mas é evidente que sua força atrativa (pois todo enigma é uma atração) depende também de uma zona de intersecção ou um espelhamento entre seu portador e nós próprios; de algo, enfim, que nos diz respeito. Como num outro conto de loucos roseano: "Agora, mesmo, a gente só escutava era o acorçôo do canto, das duas, aquela chirimia, que avocava: que era um constado de enormes diversidades desta vida, que podiam doer na gente, sem jurisprudência de motivo nem lugar, nenhum, mas pelo antes, pelo depois" ("Sorôco, sua mãe, sua filha”, in ROSA, 1964, p. 17). 
Eis aí, em plena luz do dia - e "iluminado", também, pela insistente "chirimia" das duas loucas -, o penumbroso e fantasmal território que o louco habita e para o qual ameaça nos atrair, com a força de demandas vindas sabe-se lá de onde, mas que em todo caso - falando com Jacques Derrida -, constituem um "desajuste" na suposta "contemporaneidade a si do presente vivo" (DERRIDA, 1994, p. 12). E sem dúvida que o caráter espectral dessas demandas torna interessante a aproximação do louco com o espectro derridiano. Como este, as loucas de Rosa nos afiguram portadoras de um "efeito de viseira" (DERRIDA, 1994, p. 23), um olhar que se esquiva ao nosso para reforçar a potência de sua injunção enigmática - mas aqui, também, um olhar que parece se esquivar por dentro de nós, sondando nossas próprias “diversidades”. E não só um olhar como uma voz, esta por sua vez uma força "que avoca"; uma força, portanto, que pelo menos promete (ou ameaça) suprimir a distância incomensurável entre os seres - ou entes, indivíduos, sujeitos ou como quer que denominemos os exemplares da dita espécie humana.

Para Derrida, não custa lembrar, o espectro também se liga a uma promessa: a promessa de um "messianismo sem messias", ligada, por sua vez, a uma demanda de uma "justiça infinita", ou seja, a uma exigência infinita de justiça. Para além, no entanto, dessa espécie de imperativo ético - que Derrida, no entanto, busca distinguir de um imperativo regulador como o "supra-sensível" kantiano, além de afirmá-lo como indesconstrutível -, a "promessa-ou-ameaça" que se entrevê acima guarda um outro sentido, ou melhor, é gerada por um outro sentimento: o de uma zona fronteiriça entre o si-mesmo e o outro, uma "zona empática" ativada no presente vivo, ainda que alçando-o ou deixando-nos entrever algo para além dele. Assim, o louco roseano sublinha um dado, certamente não ausente, porém, secundário no espectro derridiano - ou, pelo menos, "anterior" à injunção ética a que ele se liga, sintetizada por Derrida no motivo do juramento exigido pelo espectro $^{1}$-, que é o que podemos denominar uma força emanante, oposta à imanência de uma configuração espiritual, egótica ou identitária qualquer, embora dependente de uma dada "configuração específica" e seu efeito enigmático. Evidentemente, também de nós, de nossa "fenomenologia" do louco,

${ }^{1}$ E se nesse ponto a lembrança do pacto no Grande sertão é inevitável, também é preciso lembrar o quanto a "aparição" desse episódio é, além de menos visível e mais fugidia, menos antropo-figural e muito mais e caótico-natural do que o fantasma do pai de Hamlet, principal figura de que Derrida se vale para delinear seu motivo do espectro. 
o sentimento dessa "emanência" emana; o que, afinal, torna mais complexa a singular-heterogeneidade do processo.

Assim, o espaço entre uma enunciação que reconhece a precariedade de qualquer "normalidade" e outra que insiste em afirmar essa última a todo custo - em outros termos, uma que assume a instabilidade identitária constitutiva do "ser social" e outra que reivindica, ainda que paradoxalmente, a integridade e autonomia de um si-mesmo reflexivo - pode ser propício para explorar os infinitos matizes fenomenológicos reconhecíveis em seus interstícios, ou, quando menos, para forjar um jogo dialético (ou um jogo de dialéticas), que guarde ou ative algo da complexidade dessas relações. Mas se a noção de dialética nos parece fundamental para sublinhar o caráter contraditório e as formas freqüentemente duais de tais relações, a idéia de jogo deve indicar o zelo por uma liberdade em nossas próprias estratégias relacionais, assim como a irredutibilidade de seus elementos a quaisquer sínteses subsunsoras. Por outro lado, nem aquela noção nem esse "zelo" devem condicionar nem o compromisso de um olhar e escutar em volta, nem as ocasionais miradas nos espelhos ou fragmentos contrastivos - ou seja, os "lances comparativos" -, que pontuarão as leituras aqui empreendidas, e das quais a auto-reflexão crítico-teórica deverá fazer parte. O que talvez dê a este passeio por textos roseanos e machadianos um certo ar de loucura; mas pelo menos, quem sabe, de uma loucura com algum método.

\section{O “quem?" Da palmeira, o pertubador da desordem e a turba oscilante}

A experiência do texto literário não rompe ou afronta assim, tão diretamente, nossa percepção cotidiana da realidade que não deixe de se submeter, também ela, a certos "padrões de normalidade"; padrões, é claro, sempre variáveis, relativos a tantas coisas, talvez, quanto as que compõem a riqueza do próprio texto. Mas ainda assim eles condicionam, e por isso uma fruição profunda deve ser um exercício de autoproblematização incessante, o exercício de um auscultar das intuições e inquietações, assim como de desconfiança das certezas fáceis demais, que informam uma primeira, segunda ou quantas forem as leituras. Mas há momentos em que uma espécie de pacificação interior se produz no leitor, e - ainda que tudo não passe de uma ilusão, ou um lenitivo ou antídoto contra uma vertigem sem fim - nesses momentos ele pode reivindicar para suas hipóteses o estatuto, talvez, de alucinações críveis, ou então de disparates luminosos, inclusive no sentido de 
iluminarem algo naquilo que os olhos percorreram e o espírito quer tocar. É verdade que aí os deslizamentos normativos voltam a se produzir, mas quem disse que a própria arte se manteve alheia à força de atração (ou sucção) do "normal"?

E quem, afinal, estabelece as divisões desse campo? Onde se localiza nele, por exemplo, a própria intuição? Pois se formos pensar "intuitivamente" no que difere as narrativas de loucos de Rosa e Machado, talvez cheguemos ao insight de que a diferença consiste na claridade de umas e no sombrio das outras. Ora, vê-se muito claramente o contraste entre o êxtase coletivo, musical e, além disso, solidário do final se "Sorôco", assim como do final ainda mais carnavalesco - porque glorioso no naufrágio da "normalidade" dolorosa, além de apimentado pelo humor - de "Darandina", com o destino verdadeiramente sombrio, por exemplo, de Simão Bacamarte e Rubião (e um pouco menos de Quincas Borba, que ao menos morre cercado pela quase-certeza da "verdade" e por duas amizades afinal sinceras - a do cão mais que a do homem, é claro). Mas até que ponto a justeza dessas intuições-percepções deriva de um sentimento efetivo de seus "objetos" ou apenas de certos clichês críticos?

Retomemos nossa primeira aproximação contrastiva, ainda filtrada por esses clichês. Há um aspecto muito evidente pelo qual "O alienista" e "Darandina" se assemelham: a sátira às conclusões abstrusas de seus respectivos "psiquiatristas", na expressão do narrador de Rosa. No entanto, enquanto na novela de Machado tanto essas falas quanto as que elas buscam "normalizar" se submetem à hegemonia de uma intencionalidade crítico-irônica (e, portanto, fundamentalmente "racional"), no conto de Rosa o que predomina são a voz e os gestos de um "psiquiartista", que investem a narrativa de uma dimensão à qual podemos chamar de "mítico-poética"; poética não no sentido genérico, estético-composicional, mas no de cultivo de um certo lirismo, e mítica no sentido um tanto vago de retorno a uma espécie de tempo primordial, de "encantamento perdido": "E, pronto, refez-se no mundo o mito, dito que desataram a dar-se, para nós, urbanos, os portentosos fatos, enchendo explodidamente o dia: de chinfrim, afã e lufa-lufa" (ROSA, 1964, p. 136).

Como se vê, o "mítico" parelha aqui com o mágico e o lúdico - ligandose também, portanto, ao resgate de uma "infância" -, o que os substantivos algo sinestésicos encarregados de designar as turbulências do dia sem dúvida reforçam. Mas o gracioso da linguagem indica pelo menos mais duas 
coisas, aliás um tanto díspares: primeiro, que também aqui a ironia pode estar presente, participando da configuração ambígua do conto; segundo, o quanto a "presença plena" do louco afeta o próprio discurso do narrador, a cargo - importa notar -, de ninguém menos que um funcionário de um Instituto para loucos. A loucura como sabedoria, como intuição luminosa e mesmo enunciação de uma "verdade profunda". Nesse ponto, a diferença com "O alienista" é marcante: embora uma busca obsessiva e um determinado gesto lembrem essa "dimensão" do louco na novela machadiana, ela está evidentemente ausente desta. O topos do louco-visionário não é novo, mas quantas vezes ele se investiu da beleza radiante da aceitação plena do paradoxo da existência como nessa declaração do dandarim $^{2}$ roseano?

- "Viver é impossível!" - o dito declarado assim, tão empírico e anermenêutico, só através do egoísmo da lógica. Mas, menos como um galhofeiro estapafúrdio, ou alucinado burlão, pendo a ouvir, antes em leal tom e generoso. Era um revelar em favor de todos, instruía-nos de verdadeira verdade. (ROSA, 1964, p. 140)

Entretanto, a positividade plena que quase sempre emana desse personagem pode nublar elementos menos evidentes no conto, mas que não podem ser desprezados sob pena de suprimirmos o que há de ambíguo e enigmático no próprio louco. Qual, por exemplo, a função do estranho jogo que se estabelece entre ele e o Secretário de Finanças Públicas pelo qual o primeiro se faz passar? À primeira vista, podemos lhe atribuir, no máximo, algum efeito contrastivo e humorístico, incluindo a "deixa" para pequenas ironias políticas (via das quais, por sinal, "Darandina" se aproxima bastante de "O alienista"); mas isso não é suficiente para explicar o espaço bastante considerável que é concedido a esse jogo, que tensiona mais da metade da narrativa. É o que nos leva a perguntar se a questão de o louco ser ou não ser uma determinada pessoa não deixa entrever outra, mais ampla, talvez a de ser ou não ser alguém.

\footnotetext{
${ }^{2}$ Essa derivação de "darandina" é nossa, e obviamente remete a outro personagem roseano, não menos luminoso e ambíguo. Aparentemente, o título do conto remete a um verbo conjugado no corpo do texto - "dandinava" -, por sua vez talvez derivado de "dândi": é em referência ao "insuspeitado estilo" do personagem que a palavra surge (ROSA, 1964, p. 146). O "darandim" seria, assim, algo como um louco com estilo.
} 
Quanto a isso, aliás, é ele mesmo quem afirma, com a mesma segurança da outra frase: "Eu nunca me entendi por gente!" (ROSA, 1964, p. 139). No entanto, o que o jogo identitário com o político e burocrata parece fazer é algo mais: algo como afirmar uma impossibilidade. Se ao longo de boa parte do conto somos levados a acreditar numa falsa identidade, que se desvanece de súbito para não dar lugar a nenhuma outra, isso não pode ter outro efeito senão o de atirar o louco num limbo identitário. Talvez para benefício seu, mas certamente prejuízo nosso: não, neste mundo os burocratas, políticos e economistas não se tornam loucos líricos, capazes de devolver, do alto de uma palmeira, em pleno meio-dia, a pureza de uma idade mítica à vida; nem eles nem, pelo visto, qualquer cidadão (mesmo fictício) portador de um registro de identidade. É nessa constatação que ao lirismo desse conto se soma uma sutil melancolia. Como num pesadelo hoffmaniano ao contrário, o Secretário de Finanças é a aparição de um "indivíduo real", um perturbador da desordem: o sósia, o duplo infeliz do louco feliz, o "vero e são, existente (...) - ipso" (ROSA, 1964, p. 144), o triste exemplar da humanidade em cuja face alguém vislumbrou, num sonho carnavalesco, a alegria libertina de um louco, de um "ninguém, nulo, joão, nada" (ROSA, 1964, p. 145).

Mas o que sugerimos é que o jogo identitário entre o louco e o burocrata não constitui apenas um contraste: ele funciona como a tematização de um disparate ficcional, como se fosse possível e necessário distinguir uma ficção-verdade de uma ficção-impossibilidade; no mínimo, ele instaura uma tensão entre esses níveis da ficcionalidade roseana. Nesse sentido, não é a nulidade identitária do personagem sua marca mais importante, e sim o caráter irrespondível da interrogação: “E quem e que era?” (ROSA, 1964, p. 145). Em suma, estamos diante de um personagem duplamente fictício.

Daí, talvez, esse mesmo jogo servir como mediação para um motivo que, ao contrário do que pode parecer a princípio, não se reduz às ironias de fundo político: o do embuste. É o próprio Secretário quem, anunciandose, acusa o louco de "calúnia, embuste" (ROSA, 1964, p. 145); antes dele, porém, o povo - identificando o louco justamente com ele - já bradara: "Demagogo! Demagogo!". E o fato é que um certo, digamos, "talento para as massas" não falta ao homem encarapitado na palmeira; o que evidentemente não diz tudo mas já deixa entrever o fundamental: trata-se de um louco que, nas palavras do capelão postado ao lado do narrador, "Tem arte..." (ROSA, 1964, p. 137). Ou nas do dr. Bilôlo: "É um gênio!” (ROSA, 
1964, p. 141). Em suma, se uma espécie de pureza infantil é necessária para sua vitória sobre o mundo, ela não é suficiente, pois não prescinde de engenho e arte $e^{3}$ Por isso, o darandim é também um "personagente, em sua sicofância (...): com extraordinária acuidade de percepção e alto senso de oportunidade" (ROSA, 1964, p. 141).

O segundo neologismo condensa a operação: a "sicofância", ou o sicofantismo como infância, como "retorno mítico". Um dos lugares de intersecção desses topoi (o mítico e o embuste) é o circense: “- 'É de circo...' - alguém sus sussurrou-me, o dr. Enéias ou Sandoval. O homem tudo podia, a gente sem certeza disso. Seja se com simulagens e fictâncias?" (ROSA, 1964, p. 142). Que não se trata de um mero embuste, o desse louco com dons retórico-circenses, verifica-se, primeiro, naquilo que designamos como a força emanante do louco, uma força não só sedutora mas, sobretudo, desestabilizadora, capaz de lançar a multidão nos "fluxos e refluxos" (ROSA, 1964, p. 141), de uma oscilação que só encontrará algum equilíbrio num gesto ambíguo. Em segundo lugar, na espécie de crise de sobriedade que o acomete, quando ele surge em "doente consciência": "e tinha medo e tinha horror - de tão novamente humano" (ROSA, 1964, p. 148). Mas esse “impasse da mágica" (idem) dura pouco, e quando o personagem desce ao solo, recolhe não as roupas das quais havia se desfeito, e sim "a alma de entre os pés” (ROSA, 1964, p. 149); e aí, então, "botou-se outro. Aprumou o corpo, desnudo, definitivo" (p. 149). Aqui, portanto, o embuste não constitui uma manipulação instrumental do outro, e sim um modo de tornar-se outro. As implicações dessa operação na poética roseana são evidentes: vimos como o motivo do embuste desliza facilmente para os do artifício e da arte. Mas se isso obriga a relativizar uma leitura excessivamente valorativa dos aspectos "míticos" do conto, também exige que se vá além da mera retórica4: é ao drama de uma "busca de autenticidade" que a retórica se presta nas mãos de Rosa, e justamente isso ganha aqui uma dimensão metaficcional.

Mas que "autenticidade" é essa, que diz respeito não ao reencontro com um si-mesmo, e sim à assunção de uma alteridade enigmática, uma alteridade, digamos, identitariamente inviável? É evidente que essa alteridade

${ }^{3}$ É inevitável, nesse ponto, a lembrança de outro conto roseano no qual os temas da arte e - aqui explicitamente -, da infância também se articulam a uma espécie de êxtase ou disparate coletivo: "Pirlimpsiquice", talvez a mais "mágica" das Primeiras histórias.

${ }^{4}$ Para uma leitura de Grande sertão: veredas atenta a essa duplicidade da prosa roseana, cf. a de Suzi Frankl Sperber (1982). 
não pode ser enunciada como tal - como portadora de uma "autenticidade" -, à custa apenas desse enigmático ou des-identitário, ou seja, sem a afirmação de determinados sentimentos compartilháveis, e entre estes é difícil não reconhecer a força de uma recusa. Uma recusa, aliás, enunciada quase explicitamente pelo próprio personagem, que não apenas se gaba de jamais ter se entendido "como gente" como reivindica: "Minha natureza não pode dar saltos?” (p. 146). É verdade que há nesses "saltos" um sentimento de liberdade para além de qualquer conflito, mas o contexto "pragmático", ou melhor, a efetividade pragmática de sua enunciação não pode ser dissociada do embate "real" que se trava, ou seja, do obstáculo que lhe impõe a "realidade".

No entanto, sublinhar algo como uma dimensão, digamos, "romântica" do conto de Rosa é sem dúvida uma operação complicada. Veja-se, por exemplo, a configuração um tanto irônica e paradoxal, em "Darandina", de um dos motivos românticos mais importantes, que é o do heroísmo. Por mais que esse motivo ganhe feições problemáticas no próprio romantismo, inclusive em sua relação com a idéia de coletividade, o que temos aqui parece extrapolar a afirmação de qualquer idealismo - a, digamos, "base intocável" do heroísmo romântico -, ou quando menos dissolvê-lo numa ambigüidade indecidível. E como negar a feição paródica das palavras de ordem bradadas pelo louco no momento em que, passado o momento de lucidez, ele recupera o domínio sobre a multidão? "Apenas proclamou: - 'Viva a luta! Viva a Liberdade!' -, nu, adão, psiquiartista. Frenéticos, o ovacionaram, às dezenas de milhares se abalavam" (ROSA, 1964, p. 149). Ao mesmo tempo, sem dúvida a nudez tão desinibida do personagem carregado pelo povo, ainda mais em contraste com a angústia do instante de sobriedade vivido há pouco, confere a esse fecho o sentido de algo mais do que um gesto retórico ou circense-embusteiro.

Ainda assim, sem dúvida é essa última dimensão do louco, muito mais do que sua condição de "iluminado", que seduz a multidão, e isso assinala o lugar da principal força emanante que participa da configuração do personagem. Na passagem mesma em que é acusado de demagogia, é com um gesto circense que ele recupera as simpatias populares: "Em suave e súbito, deu-se que se mexera, a marombar, e por causa. Daí, deixando cair... um sapato!". Inversamente, quando surge sóbrio dentre as folhas, na miséria de sua lucidez, a reação coletiva não podia ser pior: "Feros, ferozes. Ele estava são. Vesânicos, queriam linchá-lo" (ROSA, 1964, p. 148). E se o que quer 
que a loucura contenha de "profundo" é indissociável da angústia dessa passagem, naturalmente também essa "profundidade" é recusada na hostilidade popular.

Mas o que tudo isso deixa entrever, no fim das contas, senão a relação dessa coletividade roseana com um determinado espelho? A singularidade do outro nunca é suficiente para impedir que ele se constitua, em algum grau, de alguma forma e em algum momento, como um espelho contrastivo para nossos próprios gestos, concepções etc. As expectativas depositadas pelos populares no darandim contêm a demanda de um espelhamento desse tipo: um espelhamento que dissolva ou pelo menos amplie positiva e "libertariamente" - o que quer que isso signifique, e ainda que se imponha pelo paradoxo da intolerância -, as fronteiras do "ser social". A demanda, enfim, de um espelho que não reflita a covarde e medíocre face do cotidiano. Pois não é justamente uma libertação das marcas e fronteiras pisco-sociais - as roupas, a identificação e depois a des-identificação com um outro, e afinal a impossibilidade de qualquer identificação -, o que assistimos no alto da palmeira? Nesse sentido, não importa muito o quanto há de sério, paródico ou paradoxal no grito libertário do louco e na aclamação desse gesto pela multidão: de alguma forma, exprime-se aí a insatisfação - certamente mais consciente para o primeiro que para a segunda -, pela obrigação de "ser gente", ou quando menos um si-mesmo fechado numa configuração identitária. Estrídulo ou visionário, o dandarim está além - um passo que seja, e embora não despido dos rastros -, da melancolia da alienação social.

\section{A polifonia infusa e a palavra-música}

Como "Darandina", também "Sorôco, sua mãe, sua filha" tem a clareza de um dia de sol. Mas se no primeiro conto a presença do louco torna o dia quase mágico, iluminando mesmo as feições sombrias em torno (embora sem dissolver seus traços sinistros: a violência, por exemplo), no segundo a claridade tem algo de opressiva: nele, é um drama o que se desenrola sob o sol lancinante do sertão. "A hora era de muito sol", comenta o narrador, enquanto aguarda, no meio de outra multidão - bem menor, certamente -, que Sorôco leve sua mãe e sua filha até o trem que irá levá-las, como é dito no primeiro parágrafo, "para longe, muito longe" (ROSA, 1964, p. 15). Mas também aqui as pessoas em torno não permanecem passivas ao que presenciam, manifestando sua solidariedade a Sorôco - "Todos diziam a ele seus respeitos, de dó" (ROSA, 1964, p. 16) -, numa empatia coletiva que 
afinal ganha dimensões extáticas: quando Sorôco se põe a cantar, seja por desabafo ou por também nele aflorar a loucura, a mesma cantiga desatinada das duas mulheres, a pequena multidão que o acompanha faz o mesmo: "E foi sem combinação, nem ninguém entendia o que se fizesse: todos, de uma vez, de dó do Sorôco, principiaram também a acompanhar aquele canto sem razão. E com as vozes tão altas!" (ROSA, 1964, p. 18).

Também esse fecho, naturalmente, evidencia a dimensão "mítico-poética" da prosa roseana. Aqui, porém, o motivo em torno do qual se articulam os sentimentos em jogo não é o circense, e sim a própria música, e o tom geral é de uma comoção muito distante do humor do outro conto. Mas se, sob a égide da música, solidariedade e loucura se avizinham de uma forma que, novamente, tem algo de "mágico", também aqui a claridade e a musicalidade excessivas arriscam a embotar os sentidos; o que aliás talvez esteja longe de ser um efeito do acaso. Uma espécie de "propensão generalizante" envolve todo esse conto: fora o trio de protagonistas do título e os encarregados de conduzir as loucas a seu destino, as demais figuras humanas são todas referidas de forma genérica, englobadas no "povo"; aliás, são menos figuras ou personagens do que simples vozes e gestos, às vezes apenas latentes. Também em "Darandina" a multidão é tratada genericamente, mas não apenas seus gestos contêm "fluxos e refluxos" como as falas individuais são quase sempre identificadas, o que evidencia suas eventuais discrepâncias. Em "Sorôco", inversamente, a ausência de identificação das vozes tem o efeito - talvez o propósito -, de embotar as diferenças.

Não obstante, é o próprio narrador quem, logo no início, chama atenção para as ambigüidades de uma das figurações mais importantes do conto, num gesto, talvez, um tanto sugestivo para o leitor: "Não era um vagão comum de passageiros, de primeira, só que mais vistoso, todo novo. A gente reparando, notava as diferenças" (ROSA, 1964, p. 15). A descrição diz respeito ao vagão que levará a mãe e a filha de Sorôco, e se de início as diferenças em relação a um "vagão comum" parecem positivas, logo em seguida a situação se inverte: "Assim repartido em dois..." (ROSA, 1964, p. 15). Já no primeiro parágrafo, portanto, nos deparamos com a marca de uma ambigüidade formada por pólos de sentidos pouco precisos: de um lado o luxo, de outro o encarceramento, ou algo próximo da opressão. Veremos como a configuração dessa polaridade depende de outros elementos, ao mesmo tempo que desliza para outras oposições, relativas a demandas veladas ou silenciadas ao longo de todo o conto. Por enquanto, cumpre 
sublinhar a evidente negatividade que participa dessa descrição inicial, e que logo adiante se investirá de um sentido marcadamente simbólico:

O carro lembrava um canoão no seco, navio. A gente olhava: nas reluzências do ar, parecia que ele estava torto, que nas pontas se empinava. O borco bojudo do telhadilho dele alumiava em preto. Parecia coisa de invento de muita distância, sem piedade nenhuma, e que a gente não pudesse imaginar direito nem se acostumar de ver, e não sendo de ninguém. (ROSA, 1964, p. 15).

Impossível não reconhecer nessa segunda descrição a imagem de um barco da morte, de partida por algum Aqueronte; um veículo, em todo caso, impiedoso e enigmático demais para ser deste mundo. Ainda voltaremos a essa passagem, mas agora talvez seja mais pertinente retomar nosso motivo das vozes.

Nossa hipótese óbvia é a de que, reparando melhor, também as vozes e os gestos esquivos que pontuam o conto se mostram marcados por diferenças e ambigüidades das quais a negatividade participa. Antes de mais nada, que pessoas são essas que aguardam e se solidarizam com Sorôco? Não estamos num conglomerado urbano como do outro conto, e sim numa província interiorana, mas esta já possui sua pequena "massa" urbana: "Sempre chegava mais povo - o movimento" (ROSA, 1964, p. 15). No contexto do conto, a idéia de "movimento" empresta aos espectadores do drama de Sorôco um sentimento não muito distante da expectativa de quem acompanha um espetáculo: "Alguém deu aviso: - 'Eles vêm!...' Apontavam, da Rua de Baixo, onde morava Sorôco" (ROSA, 1964, p. 16). E não é essa expectativa semelhante à de quem, por exemplo, se deslumbra com o luxo de um vagão de primeira classe? Se estivermos corretos, as descrições do vagão - à quais ainda voltaremos -, não visam ou dizem respeito apenas à nossa recepção, mas também à desses expectantes.

À primeira vista, o enredo do conto delineia e faz emergir aos poucos uma espécie de solidariedade orgânica entre as pessoas, como se todos integrassem uma grande família; no entanto, não é tão fácil determinar o lugar dessa solidariedade numa frase como essa: "As pessoas não queriam poder ficar se entristecendo, conversavam, cada uma porfiando no falar com sensatez, como sabendo mais do que os outros a prática do acontecer das coisas" (ROSA, 1964, p. 15). Sem dúvida, é mais fácil reconhecer que o drama, nesse momento - ainda em seu preâmbulo, ou 
melhor, na armação de sua cena -, serve de pretexto para a exibição de vaidades e aparências, que o registro estilístico apenas minimiza ("falar com sensatez"). Também a solidão de Sorôco recebe um tratamento quase eufemístico, graças sobretudo ao tom de familiaridade das falas em torno. No entanto, nessas mesmas falas ela se deixa entrever, e de forma um tanto sinistra:

O que os outros se diziam: que Sorôco tinha tido muita paciência. Sendo que não ia sentir falta dessas transtornadas pobrezinhas, era até um alívio. Isso não tinha cura, elas não iam voltar, nunca mais. De antes, Sorôco agüentara de repassar tantas desgraças, de morar com as duas, pelejava. Daí, com os anos, elas pioraram, ele não dava mais conta, teve de chamar ajuda, que foi preciso. Tiveram que olhar em socorro dele, determinar de dar as providências, de mercê. Quem pagava tudo era o Governo, que tinha mandado o carro. Por forma que, por força disso, agora iam remir com as duas, em hospícios. O se seguir. (ROSA, 1964, p. 16-17).

Note-se como o tom familiar e piedoso deriva para um registro burocrático, quase acintoso na sutil, mas inequívoca indiferença que exprime. Tão sutil e inequívoca, aliás, quanto a ironia roseana: o parágrafo transcrito se segue à menção às manifestações de dó e "respeitos" por Sorôco, às quais ele respondia "Deus vos pague essa despesa”. Assim, é difícil deixar de ver o início da citação ("O que os outros se diziam”), como uma referência a um falar pelas costas, ou, talvez, um falar de outras vozes, já que o tom aparente de uma familiaridade uniforme, sem contradições, parece parte de uma estratégia roseana; uma estratégia calcada, pode-se dizer, numa "infusão de vozes", ou, quem sabe, uma polifonia infusa. Que dizer, então, do trecho que se segue?

Nessa diligência, os que iam com elas, por bem-fazer, na viagem comprida, eram o Nenêgo, despachado e animoso, e o José Abençoado, pessoa de muita cautela, estes serviam para ter mão nelas, em toda juntura. E subiam no carro uns rapazinhos, carregando as trouxas e malas, e as coisas de comer, muitas, que não ima fazer míngua, os embrulhos de pão. Por derradeiro, o Nenêgo ainda se apareceu na plataforma, para os gestos de que tudo ia em ordem. Elas não haviam de dar trabalhos. (ROSA, 1964, p. 17). 
Novamente, o registro é atenuante, inclusive nos nomes e atributos dos homens encarregados de "ter as mãos nelas, em toda juntura", assegurando que as duas mulheres não irão "dar trabalhos" (ROSA, 1964, p. 17). Note-se ainda a sugestão de que a população garantiu o suprimento das necessidades alimentares das loucas, numa viagem, entretanto, que se afigura muito claramente - e mais, talvez, aos olhos de quem vê do que de quem a fará -, como uma viagem para a morte. Nesse sentido, a morte-repressão também está nos gestos dos que a aceitam (e só tardiamente se condoem com a perda de Sorôco). Não é esta, afinal, a outra face do estranho vagão? Não é isso o que os expectantes reconhecem, e talvez busquem, no triste espetáculo do dia - triste mas, em todo caso, mais intenso do que o espetáculo diário dos vagões de primeira?

Mas é claro que essa "demanda de espetáculo" não é o único sentimento em jogo. Para além dela, há as demandas que se ligam aos sentidos enigmáticos da própria loucura e, claro, sua contraface normal e normatizadora. A princípio, a mesma ambigüidade do carro parece se refletir na dupla de loucas: uma portando um esplendor e a outra um luto. Ao contrário, porém, do luxo do vagão, a alegria da moça com seus olhos de "santos e espantados", "enfeitada de disparates", com "panos e papéis, de diversas cores" (ROSA, 1964, p. 16), é uma alegria de quem "não queria dar-se em espetáculo, mas representava de outroras grandezas, impossíveis” (ROSA, 1964, p. 17); e ao contrário do aspecto algo terrífico do barco-vagão, é um luto tranqüilo, na conjunção talvez ainda mais estranha da morte com o amor, que se espelha nos olhos da velha avó: "Mas a gente viu a velha olhar para ela, com um encantamento de pressentimento muito antigo - um amor extremoso" (ROSA, 1964, p. 17). É esta a dupla força "que avoca" no canto dessas loucas: a alegria de uma plenitude impossível e a tranqüilidade profunda e assustadora de um olhar amoroso para o abismo da outra.

Que fazer diante de tal força? O desejo de livrar-se dela é indisfarçável - "Tomara aquilo se acabasse" (ROSA, 1964, p. 17) -, mas ela não seria tão grande se não dissesse respeito às "enormes diversidades desta vida" (ROSA, 1964, p. 17), ou seja, às diversidades e adversidades instaladas no âmago da dita normalidade e, é claro, dos que zelam por ela. Por isso, a identificação coletiva com o canto de Sorôco não traz apenas a força de uma solidariedade empática, mas também de uma catarse coletiva: ela é a possibilidade de uma "fuga" segura e provisória do "normal", e nisso não deixa de configurar um paradoxo em relação à própria solidariedade. Esta, 
naturalmente, não deixa de constituir uma peça importante no conto; negar isto seria desprezar o que nele se diz textualmente: "de dó do Sorôco..." (ROSA, 1964, p. 18); ou um pouco antes: "Todos, no arregalado respeito, tinham as vistas neblinadas" (ROSA, 1964, p. 18). A comoção é sincera, mas ela tem seu limite demarcado pela distância que ainda separa, de um lado, uma profusão de "si-mesmos" em algum grau ainda zelosos de sua integridade psíquica e identitária e, do outro, uma alteridade na qual essa integridade já não é tão segura.

A despeito de sua enunciação poética, esse limite é também um limite temporal e espacial: "A gente estava levando agora o Sorôco para a casa dele, de verdade. A gente, com ele, ia até aonde ia aquela cantiga” (ROSA, 1964, p. 18). Aliás, nas próprias marcas relativas ao tempo da enunciação é visível um limite não só temporal como relativo a fronteiras tanto sociais quanto psíquicas, ou seja, a uma memória simultaneamente individual e coletiva: "Foi o de não sair mais da memória. Foi um caso sem comparação" (ROSA, 1964, p. 18). E se a solidariedade reintegra Sorôco - que antes voltava para casa "como se estivesse indo para longe, fora de conta" (ROSA, 1964, p. 18) - num espaço coletivo mais amplo, não deixa de reafirmar um espaço específico para ele. Enfim, o gesto solidário também contém um sutil zelo por uma sociabilidade "razoável", inclusive com seus espaços demarcados.

Naturalmente, isso pressupõe a possibilidade de uma espécie de "identificação relativa" com o louco. Em "Darandina", essa possibilidade se dava pelo aspecto circense, com seu quê de superficial, das "dandinagens" do louco. Aqui, evidentemente, e como já adiantamos, ela se dá sob o signo da música, ou seja, da música enquanto força "envolvente", capaz de produzir uma espécie de "transporte". Mas sublinhar isso não é suficiente, pois essa força também tem implicações na esfera do dizer. Constituída pela junção de letra e música, a canção das loucas é descrita como uma cantiga que "não vigorava certa, nem no tom nem no se-dizer das palavras - o nenhum". Assim, se imaginarmos o canto coletivo final, teremos uma cena bastante curiosa, na qual todos cantam diferentemente a mesma coisa: uma espécie de babel harmônica, ou que extrai sua harmonia do caos.

Harmonia e plenitude, pois se trata também, evidentemente, de um êxtase coletivo. Assim, talvez possamos ver aqui uma imagem poética daquilo que designamos como uma "polifonia infusa" no conto; ou, melhor, o desvelamento de tal polifonia como seu princípio poético, tanto no sentido composicional quanto no sentido de um lirismo ligado a uma certa 
"transcendência". Transcendência, quando menos, dos limites da linguagem humana: o êxtase da loucura-música é também o êxtase da palavramúsica, da palavra que se faz integralmente música ao se livrar de sua carga significante.

Nesse sentido, comparado a "Darandina", "Sorôco, sua mãe, sua filha" reforça a dimensão mítico-poética da prosa roseana. Mas não há aqui, também, a força de uma refinada "psicologia social", e mesmo uma sutil sociologia? Pois embora apenas delineadas, as relações sociais deixam aqui marcas profundas daquilo que possuem enquanto relações de poder. E isso não diz respeito apenas à situação das loucas; pelo contrário: justamente nisso talvez resida segredo do suspeitíssimo tom de familiaridade do conto. Afinal, essa província roseana está longe de ser um espaço marcado apenas pela afetividade e proximidade humana das sociedades pré-capitalistas, e talvez o sintoma mais forte disso seja a forma como o narrador designa o poder desconhecido que parece emanar do vagão que levará as mulheres: algo "sem piedade nenhuma" e "não sendo de ninguém". Eis os dois elementos que estabelecem alguma mensurabilidade para essa figuração da morte: a impiedade e a propriedade, sendo a segunda, talvez, a principal medida de sua força. Se lembrarmos que logo em seguida o narrador sublinha a condição de pobres dos populares ("Para o pobre, os lugares são mais longe" [ROSA, 1964, p. 15]), a comparação implícita fica mais clara: são dois poderes implacáveis que o narrador contrasta: o da propriedade e o da morte, o segundo tão grande que não cabe em propriedade alguma.

Ganha relevo, assim, outra voz fantasmal que se dirige a Sorôco: "E lhe falaram: - 'O mundo está dessa forma...' ”. A que exatamente se refere "o mundo": às loucas, aos que as aprisionam, aos que são coniventes com isso? $\mathrm{Ou}$, quem sabe, temos aqui uma retomada de um dos grandes temas do Grande sertão: o dos "tempos loucos", em que "todo-o-mundo é louco" (ROSA, 1964, p. 13), um mundo onde "manda quem é forte, com as astúcias", e para o qual "Deus mesmo, quando vier, que venha armado" (ROSA, 1984, p. 16). Um mundo, nesse sentido, não muito distante do mundo sombrio de Simão Bacamarte.

\section{O rodízio de loucos e um alienista de si mesmo}

Aliás, até que ponto nossa "intuição" a respeito do caráter sombrio de Itaguaí passa pelo crivo de uma leitura ligeira? Ora, se tomarmos "sombrio" em sentido literal, temos que reconhecer que o adjetivo se aplica pouco a 
"O alienista". Chega a ser curioso que não haja, por exemplo, nenhuma cena de calabouço ou de tortura, que o tema permitiria à exaustão - e já então corriqueiras, por exemplo, nos contos de Poe -, e mesmo pouquíssimas cenas internas na Casa Verde, o hospício e campo das "experiências" de Simão Bacamarte. Em suma, em que pese o clima opressivo de tantas páginas - sobretudo aquelas em que vemos a ação de Bacamarte se espalhar de forma implacável por toda a vila -, "O alienista" não é algo como uma história de "terror científico" - subgênero dos mais usuais no romantismo -, como "A causa secreta" chega bem mais perto de ser.

Assim, por mais sentido que haja em apontar nesse conto, por exemplo, "premonições" das atrocidades nazistas ${ }^{5}$ - sobretudo no que diz respeito ao jugo da "ciência" sobre a vida -, as diferenças também precisam ficar claras. Simão não nutre propriamente desprezo por quaisquer pessoas; aliás, para ele todos são indistintamente "dignos" (ou seja, virtuais vítimas), de seu interesse científico, e seu propósito de obter uma cura universal para os "males da alma" não se curva diante de nenhum dos "casos" que tem em mãos. Os extremos constitutivos de seu "seletivismo" têm uma abrangência muito maior do que, por exemplo, um critério de fundo "racial". Mais do que biológicos, aliás, eles são filosóficos, já que constituídos, de um lado, por uma espécie de Razão absoluta - ou seja, a crença na possibilidade de um equilíbrio perfeito das faculdades mentais e morais - e, do outro, o pólo cada vez mais abrangente (antes da espetacular "inversão" do capítulo XII) de tudo o que escapa a ela. Assim, o "quadro clínico" desse monomaníaco da razão - que até o fim ele não mesmo não entenderá - é muito mais o de um ego desmesurado, que se afirma à custa de uma espécie de fé absolutista, próxima de um delírio religioso, numa certa idéia de "ciência". Há em suas ambições, portanto - pelo menos se acreditarmos em sua incapacidade de perceber a própria vaidade -, um tipo de "pureza" ou ingenuidade que as diferem de um projeto cruel e de extermínio como o nazista. É pelo menos acreditando que presta "um bom serviço à humanidade" (MACHADO DE ASSIS, 1977, p. 13), que Simão comete seus disparates.

Isso, como veremos, é importante em vários aspectos do conto, a começar por esse dado fundamental: não raro, Machado "fala" por meio de Simão; ou seja, aquilo em que podemos reconhecer uma "intencionalidade autoral" se vale das percepções do alienista para produzir "representações"

\footnotetext{
${ }^{5}$ Cf., por exemplo, a leitura de Boris Schnaiderman (2006).
} 
e juízos críticos da realidade dita itaguaiense. $\mathrm{O}$ alvo dessa parceria pode ser, por exemplo, um "caso" de vaidade - o da própria esposa do alienista, cujo amor pelas sedas e jóias ganha ares obsessivos (MACHADO DE ASSIS, 1977, p. 44) -, ou os disparates ligados à "revolução" que depõe a Câmara de Itaguaí: os "sintomas de duplicidade e descaramento" do líder do movimento, e a "toleima" da população que o apoiou, à custa de "onze e mortos e vinte e cinco feridos", para se ver traída em sua principal reivindicação, ou seja, a destruição da Casa Verde (MACHADO DE ASSIS, 1977, p. 41). Mas nem de longe isso significa uma adesão absoluta à perspectiva do protagonista. Pelo contrário: ele é talvez o principal alvo da ironia machadiana.

Da ironia e da sátira, já que este talvez seja o mais satírico dos textos da maturidade de Machado de Assis; bem mais, inclusive, do que as Memórias póstumas de Brás Cubas, do qual é contemporâneo (pelo menos de acordo com as datas de publicação). E é sob um viés satírico que a própria loucura nos é apresentada: um viés, portanto, muito diferente da perspectiva mítico-poética que, como vimos, não deixa de informar os contos de loucos de Rosa.

Talvez seja o caso, nesse ponto, de retomarmos nosso jogo metafórico para perguntar que tipo de "claridade", ou pelo menos de jogo de luzes e sombras - já que revimos nossa "intuição" excessiva a respeito das segundas -, podemos atribuir, afinal, à estranha vila-hospício machadiana. Não se trata, evidentemente, da claridade "extática" de um louco que ilumina o cotidiano com sua presença-ausência plena, ou então o contrasta com ela. O que ocorre em "O alienista" é que uma "luz" incide de forma muito mais clara e definida sobre algo que se mostra penumbroso ou, pelo contrário, um tanto ofuscante nos contos de Rosa: a própria "loucura do cotidiano", a loucura da dita normalidade, "normalidade" esta da qual Simão Bacamarte se pretende o guardião implacável. Ao mesmo tempo, se este passa longe do espírito sádico de um Fortunato (o médico de "A causa secreta"), com suas zonas nebulosas a se sobreporem a qualquer "espírito científico", isso mostra o quão mais entranhado nele, mais indissociável dele e sua "ciência" está o próprio sinistro. No fim das contas, portanto, a própria claridade é parte do absurdo. O fato dos abusos de Simão se desenrolarem à luz do dia, a olhos vistos e quase sempre com a conivência de quem os sofre direta ou indiretamente, tal fato é parte da configuração hiperbólica que a loucura do cotidiano assume na submissão a uma força certamente mais repressiva do que a "lógica" que a rege no dia-a-dia, mas não totalmente alheia a ela. 
São, portanto, iluminações sombrias as que pontuam "O alienista". Algo sensível, por exemplo, quando Simão Bacamarte passa a "admitir como normal e exemplar o desequilíbrio das faculdades e como hipóteses patológicas todos os casos em que aquele equilibrio fosse ininterrupto" (MACHADO DE ASSIS, 1977, p. 45). Por mais grotesca que seja a espécie de rodízio de loucos que isso gera no conto, ela "implementa" a tese mais aguda e provocativa de Machado-Simão: a de que, dependendo do ponto de vista, somos todos loucos. Não é verdade, por exemplo, que há um quê de loucura em cultivar uma honestidade a toda prova num mundo corrompido? E, mais ainda, que a hipocrisia, a dissimulação, o oportunismo etc. são, em alto grau, verdadeiras normas sociais? Assim, as terapias corruptoras a que Simão se lança em seguida pretendem coroar um "dado da realidade" (dita itaguaiense), mas enquanto algo nascido dessa realidade - ou seja, que de certa forma realiza sua lógica -, e não, simplesmente, do cérebro de um cientista maluco. Nesse sentido, os "êxtases científicos" do alienista - "Uma volúpia científica alumiou os olhos de Simão Bacamarte..." (MACHADO DE ASSIS, 1977, p. 25); "com os olhos acesos da convicção científica..." (MACHADO DE ASSIS, 1977, p. 55) -, quase sempre disparatados mas não raro extremamente luminosos, podem ser vistos, em medidas sempre variáveis, como pontos de intersecção entre o olhar bacamartiano e o "gozo" da escritura e da "análise" psicossocial machadiana.

Mas ainda há um outro motivo pelo qual as metáforas da claridade e, mais ainda, da luminosidade são importantes aqui. Pois o fato é que a predominância do viés satírico não impede que formas "líricas" da loucura se manifestem, ainda que irônica ou residualmente, nesse conto. É verdade que nesse ponto é preciso cuidado: o caso, por exemplo, de "um rapaz bronco e vilão, que todos os dias, depois do almoço, fazia regularmente um discurso acadêmico, ornado de tropos, de antíteses, de apóstrofes" etc. (MACHADO DE ASSIS, 1977, p. 13), caso este apresentado como "inexplicável", pode ser visto apenas como o fruto de uma liberdade irônica. Por outro lado, se a sugestão aqui é simplesmente a de que a retórica é "transmissível" (mais ou menos como uma gripe), não podemos vislumbrar, mesmo no que há de caricatural nessa idéia, algo como uma "fenomenologia da linguagem" machadiana, ou seja, o delineamento de um penumbroso espaço de intersecção e ruptura entre linguagem e natureza? ${ }^{6}$ Nesse sentido, esse personagem

\footnotetext{
${ }^{6}$ Abordei essa questão, na obra de Machado, em um texto publicado recentemente (PAZ, 2007).
} 
não fica tão distante do dandarim roseano que reivindica para sua natureza o direito de "dar saltos".

A mais "lírica" das loucuras do conto, porém, é a de um dos "loucos por amor": um rapaz que "supunha-se estrela-d’alva, abria os braços e alargava as pernas, para dar-lhes certa feição de raios, e ficava assim horas esquecidas a perguntar se o sol já tinha saído para ele recolher-se" (MACHADO DE ASSIS, 1977, p. 13). É verdade que ainda aqui a ironia, agora anti-romântica, é inequívoca, mas ela não elimina a figuração de um amor transfigurador e um desprender-se de si que situam esse "caso" no extremo oposto ao daqueles nos quais a loucura toma uma feição principalmente "moral", e dos quais o exemplo mais importante talvez seja o do barbeiro Porfírio, líder do movimento que depõe a Câmara Municipal em reação aos abusos de Simão Bacamarte. Ao contrário de qualquer "perda de si", o que temos nesse pequeno e mal-sucedido ditador é a redução dos outros à racionalidade instrumental de um ego fechado em si mesmo; um tipo de alienação, portanto, muito mais negativamente marcada, constituída por um egocentrismo vazio que apenas o poder absoluto - ou seja, a redução de tudo à esfera de um si-mesmo -, pode preencher.

Entre estes "casos", naturalmente, viceja uma profusão de situações intermediárias, como a de um certo Mateus, que passa horas na contemplação de sua casa nova ao mesmo tempo que se oferece à contemplação dos transeuntes; ou mesmo a da esposa de Simão, com sua paixão por sedas e jóias. Em ambos os casos, o elemento egótico convive com um certo "deslumbramento" que lhe confere, quando menos, uma espécie de lirismo banal. Há ainda o vereador cujas posições flutuam ao sabor das frases de efeito, e que, portanto, deixa-se "tocar" pela retórica de forma tão profunda e banal quanto o "rapaz bronco e vilão" a que já nos referimos. Entretanto, é evidente no conto um processo pelo qual as formas e resíduos "líricos" da loucura cedem lugar à loucura enquanto sordidez e mesquinhez; um processo mais ou menos paralelo à substituição da preocupação de Simão Bacamarte com o equilíbrio propriamente mental pela preocupação com o equilíbrio moral dos itaguaienses.

Não obstante, é justamente numa imbricação da qual participa a moral que, para além inclusive do caso do homem-estrela, surge a "loucura" mais "mágica" do conto. De forma semelhante ao que ocorre nos contos de Rosa, também esse episódio envolve uma surpresa ligada a uma coletividade; aliás, ele é anunciado como "O inesperado", conforme o título do capítulo VII. 
Trata-se do capítulo que sela a vitória dos Canjicas, ou seja, da "revolução" encabeçada por Porfírio: cercado pelo "corpo de dragões" (a força policial da vila), os Canjicas têm "um instante de estupefação" (MACHADO DE ASSIS, 1977, p. 35); decididos, no entanto, a cerrar combate, ouvem os "dragões" receberem ordem de abrir fogo. É quando o "inesperado" acontece:

A derrota dos Canjicas estava iminente, quando um terço dos dragões, - qualquer que fosse o motivo, as crônicas não o declararam - passou subitamente para o lado da rebelião. Este inesperado reforço deu alma aos Canjicas, ao mesmo tempo que lançou desânimo às fileiras da legalidade. Os soldados fiéis não tiveram coragem de atacar os seus próprios camaradas, e, um a um, foram passando para eles, de modo que, ao cabo de alguns minutos, o aspecto das coisas era totalmente outro. (MACHADO DE ASSIS, 1977, p. 36).

Do ponto de vista de Simão Bacamarte, tudo não passou de uma grande "toleima" por parte do povo. Do ponto de vista dos oprimidos e ameaçados por suas práticas "científicas", porém, a revolta e, dentro dela, sobretudo o episódio dos dragões se revestem de outro sentido, ainda que de certa forma ilusório: o da luta solidária contra a opressão; mais ainda, da "loucura" de desafiar as normas dominantes em benefício de todos. Mas novamente o registro irônico - cujo alvo, evidentemente, são as turbulências sociais e os movimentos revolucionários dos séculos XVII e XIX, da Revolução Francesa à Revolta Farroupilha ${ }^{7}$ - é inequívoco. Passado o afã da revolta, à qual aliás se sucede outra e depois a "restauração", tudo é assimilado aos esquemas classificatórios de Simão Bacamarte, e nada parece restar do grande momento da solidariedade imprevista. Ainda assim, é lícito supor que a demanda a que esta buscava atender não tenha se dissolvido totalmente.

Portador da loucura mais sincera e persistente do conto, Simão Bacamarte não pode deixar, ele mesmo, de ecoar essa demanda: a demanda de um ir além da mesquinhez e do utilitarismo das convenções de uma sociedade habitada e regida por seres alienados uns dos outros e, portanto - já que não há si-mesmo que não se constitua no contato com o outro -, de si mesmos. Nesse sentido, sua decisão de trancafiar-se na Casa Verde a fim de olhar para dentro de si mesmo, em busca de algo que ele nem ao menos

\footnotetext{
${ }^{7}$ Mas o "inesperado" em questão lembra particularmente o episódio do apoio da guarda nacional aos revoltosos da Comuna de Paris, em 1871.
} 
sabe o que é, talvez constitua o mais sombrio e luminoso de seus gestos. Um gesto quase romântico, na coragem e na radicalidade, mas também na melancolia e no fracasso a que está fadado.

\section{Concluindo, então}

Se concluir pressupõe sintetizar, talvez esta seja a forma mais recomendável para dar início a estas precárias "conclusões". Em nossa primeira estação roseana, nos deparamos com uma alteridade extrema - um louco -, capaz de abalar as estruturas identitárias da dita normalidade, sem no entanto poder dissolvê-las nem deixar de refleti-las em certa medida. Na segunda, a força emanante da conjunção de outras dessas alteridades provoca uma reação coletiva que, por um lado, rompe momentaneamente as fronteiras identitárias e, por outro, as reafirma. Finalmente, em nosso aporte machadiano vimos os gestos libertários porventura identificáveis em outras tantas dessas alteridades serem absorvidos por gestos utilitários ou classificatórios, dando lugar, no entanto, a um mergulho interiorizante tão desastroso quanto, talvez, necessário. Nos três contos, de alguma forma está implicada uma dialética entre a singularidade extrema de dadas alteridades e as demandas de uma dada coletividade, e é na dupla "emanência" dessa dialética - ou seja, no que emana de seus dois pólos -, que vimos surgirem as possibilidades e os obstáculos no sentido de dissolver a própria polaridade em relações plenas, ou de uma solidariedade efetiva que ultrapasse as fronteiras identitárias.

Certamente, tanto em Rosa quanto em Machado tudo isso se articula de forma entranhada à configuração de relações e contradições sociais sem as quais o que chamamos aqui de "identitário" se torna perfeitamente vazio, ou seja, recai na idealidade vazia de uma "ipseidade"; justamente o que as demandas exigentes - dos loucos e de qualquer um de nós -, questionam de forma radical. Mas não se pode reivindicar, para um exercício de leitura, a força de um contato com uma alteridade se não se assume esse contato no âmbito da própria vida: a de quem lê, naturalmente. Nesse sentido, é preciso a humildade de tentar extrair desse percurso algo como uma "lição

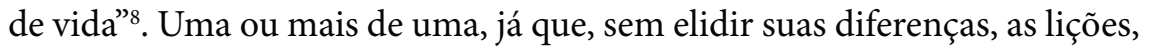
aqui, podem ser complementares: não há esperança de superação efetiva

${ }^{8}$ É este, aliás, o mote do "Exórdio" de Derrida que abre Espectros de Marx: "Alguém, vocês ou eu, se adianta e diz: eu queria aprender a viver enfim" (DERRIDA, 1994, p. 09). 
dos limites impostos pelo "ser social", ou seja, pela racionalidade técnica e instrumental da vida moderna, sem um mergulho profundo no âmago de nós mesmos, ou seja, daquilo que erigimos, bem ou mal, como nossos "si-mesmos"; mas não há mergulho interior bem sucedido, que encontre algum sentido duradouro, se não se desdobrar em direção àquela superação, ou seja, na busca sempre aberta de um encontro pleno com a infinita heterogeneidade do mundo.

E se a ausência daquele mergulho demarca um limite para os êxtases coletivos nos contos de Rosa e Machado, a ausência dessa direção é o que sela a feição propriamente alienada de seus loucos mais plenos, e da qual mesmo o dandarim da palmeira não pode escapar, cerceado como está pelas demandas oscilantes da multidão. Por outro lado, a dupla ruptura aqui entrevista - com os limites do si-mesmo e do "ser social" - é, talvez, o que ensaiam duas outras figuras, uma roseana e outra machadiana: Riobaldo e o conselheiro Aires. Duas figuras muito díspares - o primeiro um ex-cangaceiro e o segundo um ex-diplomata -, mas com pelo menos um traço em comum: o fascínio e, mais ainda, o amor pelas razões e desrazões deste mundo.

\section{Referências Bibliográficas}

DERRIDA, Jacques. Espectros de Marx. Rio de Janeiro: Relume Dumará, 1994.

MACHADO DE ASSIS, José Maria. O alienista. São Paulo: Ática, 1977.

PAZ, Ravel Giordano. Linguagem, consciência e natureza em Machado de Assis (errâncias). Revista da Anpoll, Brasília, n. 23, p. 285-305, jul./dez. 2007.

ROSA, João Guimarães. Grande Sertão: Veredas. São Paulo: Círculo do Livro, 1984.

ROSA, João Guimarães. Primeiras estórias. Rio de Janeiro: José Olympio, 1964.

SCHNAIDERMAN, Boris. "O alienista", um conto dostoievskiano? Teresa, São Paulo, n. 6/7, p. 268-273, 2006.

SPERBER, Suzi Frankl. Signo e sentimento. São Paulo: Ática, 1982. 
